\title{
GAMBARAN LAMA HARI RAWAT INAP, ASUPAN ENERGI DAN PROTEIN DENGAN STATUS GIZI PASIEN YANG MENDAPATKAN POSITIVE DIET DI RSU HOLISTIC
}

\author{
Ahmad Yani' ${ }^{1}$ Rifka Hanny' ${ }^{2}$, Restu Amalia Hermanto ${ }^{3}$ \\ 1,2,3 Program Studi Ilmu Gizi, Sekolah Tinggi Ilmu Kesehatan Holistik \\ Korespondensi Jln. Veteran, No. 272. Purwakarta.Email: ahmadyani@stikesholistic.ac.id
}

\begin{abstract}
ABSTRAK
Latar Belakang: Lama rawat inap serta asupan energi dan protein rendah dapat mempengaruhi status gizi pasien. Makanan positive diet adalah salah satu jenis terapi diet yang diberikan kepada pasien di RSU Holistic. Tujuan positive diet memberikan makanan sesuai dengan kondisi pasien untuk detoksifikasi dan mencegah serta mengurangi kerusakan jaringan tubuh. Jenis karbohidrat yang diberikan serealia organik dan umbi-umbian. Jenis protein tahu, tempe dan kacangkacangan serta protein hewani seperti ikan kembung, ikan gindara, telur dan daging ayam kampung. Sumber lemak yang diberikan minyak zaitun dan minyak jagung.
\end{abstract}

Tujuan Penelitian: Mengetahui gambaran lama hari rawat inap, asupan energi dan protein dengan status gizi pada pasien positive diet.

Metode: Penelitian ini merupakan penelitian deskriptif analitik dengan desain cross sectional yang dilakukan bulan September-November 2020. Sembilan subjek yang memenuhi kriteria inklusi diambil dengan metode consecutive sampling. Data lama hari rawat inap diambil selama pasien masuk sampai keluar rumah sakit. Data asupan energi dan protein menggunakan form food recall $3 \times 24$ jam. Data status gizi menggunakan Indeks Massa Tubuh (IMT) diambil awal pasien masuk dan saat keluar dari rumah sakit.

Hasil: Hasil penelitian ini menunjukkan sebanyak 44,4\% $(n=4)$ memiliki lama hari rawat inap panjang (8-10 hari). Sebagian besar subjek memiliki rata-rata asupan energi baik $(44,4 \%)$ dan asupan protein kurang $(77,8 \%)$. Status gizi awal masuk dengan kategori normal sebanyak 4 orang $(44,5 \%)$, dan saat keluar dari rumah sakit 5 orang $(55,6 \%)$.

Simpulan: Lama hari rawat inap yang panjang pada pasien yang mendapatkan positive diet memiliki asupan energi baik, asupan protein kurang dan status gizi normal.

Kata kunci: lama hari rawat inap, asupan positive diet, status gizi

\section{ABSTRACT}

Background: Length of hospitalization and low energy and protein intake can affect the nutritional status of patients. Positive diet food is one type of diet therapy given to patients at RSU Holistic. The purpose of a positive diet is to provide food according to the patient's condition to detoxify and prevent and reduce damage to body tissues. Types of carbohydrates given organic cereals and tubers. Types of protein tofu, tempeh and beans as well as animal protein such as mackerel, gindara fish, eggs and free-range chicken meat. Sources of fat provided olive oil and corn oil.

Objectives: To describe the length of hospitalization, energy and protein intake with nutritional status in positive diet patients. 
Methods: This study is a descriptive analytic study with a cross sectional design conducted in September-November 2020. Nine subjects who met the inclusion criteria were taken using consecutive sampling method. Data on the length of hospitalization was taken during the patient's admission to discharge from the hospital. Data on energy and protein intake using a food recall form $3 \times 24$ hours. Nutritional status data using Body Mass Index (BMI) was taken when the patient entered and when he left the hospital.

Results: The results of this study showed that $44.4 \%(n=4)$ had long hospitalization days (8-10 days). Most of the subjects had an average good energy intake (44.4\%) and low protein intake (77.8\%). Initial nutritional status included in the normal category as many as 4 people (44.5\%), and when discharged from the hospital 5 people (55.6\%).

Conclusion: Long hospitalization days in patients who received a positive diet had good energy intake, less protein intake and normal nutritional status.

Keywords: length of hospitalization, positive diet intake, nutritional status

\section{PENDAHULUAN}

Lama hari rawat inap merupakan selisih antara awal masuk pasien untuk dirawat di rumah sakit hingga pasien keluar dari rumah sakit tersebut. Penilaian mutu dan efisiensi rumah sakit didalamnya memiliki salah satu indikator penilaian yaitu lama hari rawat inap pasien, karena pada umumnya semakin lama pasien menjalani rawat inap maka dapat menyebabkan memperburuknya keadaan pasien. ${ }^{1}$ Hasil penelitian yang dilakukan di RSUD. Dr. Moewardi rata-rata pasien yang menjalani rawat inap 4-7 hari memiliki persentase tertinggi yaitu $64,1 \% .^{2}$ Lama perawatan yang memanjang disebabkan karena beberapa faktor yaitu faktor ekstrinsik dan intrinsik. Faktor ekstrinsik terdiri dari pemenuhan nutrisi yang tidak adekuat, teknik operasi, obat-obatan, sosio-ekonomi dan proses penyembuhan luka. Sedangkan faktor intrinsik terdiri dari usia, gangguan sirkulasi, nyeri, dan penyakit penyerta. ${ }^{3}$ Correia et al ${ }^{3}$ melaporkan bahwa lama rawat di rumah sakit lebih pendek terjadi pada pasien yang memiliki status gizi baik, sedangkan pada pasien yang memiliki lama hari rawat inap 6-9 hari cenderung memiliki status gizi kurang. Hal tersebut menandakan bahwa peningkatan lama hari rawat inap pasien maka berpotensi akan memiliki status gizi yang semakin menurun. Lama hari rawat inap yang terlalu lama juga dapat menyebabkan berkurangnya nafsu makan yang disebabkan oleh mual atau gejala penykit lainnya. Dalam jangka panjang hal tersebut dapat mengakibatkan terjadinya gangguan asupan gizi yang dapat mempengaruhi sistem imunitas bahkan dapat menyebabkan malagizi. ${ }^{4}$ Prevalensi malagizi terkait penyakit yang terjadi pada pasien rawat inap telah dilaporkan antara $20 \%$ sampai 50\%. Studi di Amerika Latin menunjukkan prevalensi malagizi sebesar $50,2 \%$ dan $11,2 \%$ diantaranya mengalami malagizi berat, ${ }^{3}$ sedangkan di Jerman dan Spanyol prevalensi malagizi sebesar $27,4 \%,{ }^{5}$ dan $28,9 \%{ }^{6}$.

Rumah Sakit Umum Holistic Purwakarta (RSUHP) merupakan rumah sakit yang menerapkan konsep Holistic Medicine dimana makanan merupakan obat utama untuk proses penyembuhan pasien. Sistem kedokteran holistik sangat memperhatikan asupan zat gizi yang diberikan dengan terapi diet yang berbeda dari rumah sakit konvensional pada umumnya. ${ }^{7}$ Salah satu jenis terapi diet yang diberikan yaitu positive diet. Makanan positive diet adalah makanan yang beraneka ragam, bervariasi dalam bentuk, tekstur, dan aroma yang normal namun alami dan minimal proses pengolahan. Makanan positive diet 
diberikan kepada pasien yang berdasarkan penyakitnya tidak memerlukan diet khusus. Makanan diberikan dalam bentuk mudah cerna dan disesuaikan dengan kondisi pasien. Tujuan diet makanan positive diet adalah memberikan makanan sesuai dengan kondisi pasien untuk detoksifikasi dan mencegah serta mengurangi kerusakan jaringan tubuh. Syarat diet makanan positive diet kebutuhan gizi disesuaikan dengan kondisi pasien. Jenis karbohidrat yang diberikan adalah serealia, beras organik dan umbi-umbian, sumber protein yang diberikan antara lain tahu, tempe dan kacang-kacangan serta protein hewani seperti ikan kembung, ikan gindara, telur dan daging ayam kampung. Jenis lemak/minyak yang diberikan terbatas hanya minyak zaitun dan minyak jagung yang digunakan untuk menumis atau dressing salad. Porsi pemberian makanan positive diet

\section{METODE PENELITIAN}

Penelitian ini merupakan penelitian deskriptif analitik dengan desain cross sectional yang dilakukan pada bulan September-November 2020. Penelitian ini telah dinyatakan lolos etik oleh Komisi Etik Penelitian Kesehatan Universitas Pembangunan Negeri Veteran Jakarta Nomor: 2812/XII/2020/KEPK dan izin penelitian dari RSUHP. Sembilan subjek yang memenuhi kriteria inklusi bersedia menjadi subjek penelitian, sedang mendapatkan positive diet dan dapat berkomunikasi dengan baik, diambil dengan metode consecutive sampling. Data lama hari rawat inap diambil selama pasien masuk sampai keluar rumah sakit. Hasil ukur lama hari rawat inap dikelompokan menjadi 7 hari, 8-10 hari, dan $\geq 11$ hari. Data asupan energi dan protein menggunakan form food recall 3 x 24 jam yang dikumpulkan tidak di hari yang berturut-turut selama rawat inap. Hasil ukur asupan energi dan protein dikelompokan menjadi sangat terbagi menjadi porsi kecil $(50 \%$ kebutuhan kalori), porsi sedang (75$100 \%$ kebutuhan kalori), dan porsi besar $(>100 \%$ kebutuhan kalori) disesuaikan dengan kemampuan pasien untuk menghabiskan makanan selama perawatan.

Berdasarkan profil kesehatan Kabupaten Purwakarta Tahun 2019, RSUHP memiliki rata-rata lama hari rawat pasien adalah 7-14 hari lebih panjang dari rumah sakit pada umumnya. ${ }^{8}$ Berdasarkan hasil penelitian-penelitian sebelumnya yang telah menjelaskan bahwa setiap pasien yang memiliki lama rawat inap lebih panjang cenderung memiliki status gizi yang menurun atau kurang, oleh karena itu penulis tertarik untuk melakukan penelitian tentang gambaran lama hari rawat inap, asupan energi dan protein dengan status gizi pasien positive diet $\mathrm{di}$ RSUHP.

kurang ( $\leq 50 \%)$, kurang (51\%-79\%), baik (80\%-100\%) dan lebih ( $\geq 100 \%)$ dari kebutuhan. Kecukupan asupan energi dan protein dibandingkan dengan kebutuhan masing-masing subjek. Penentuan status gizi menggunakan Indeks Massa Tubuh (IMT) dengan pengukuran berat badan dan tinggi badan menggunakan timbangan digital dan microtoise dengan tingkat ketelitian $0,1 \mathrm{~kg}$ dan $0,1 \mathrm{~cm}$. pengukuran berat bdan dan tinggi badan dilakukan saat pasien masuk dan pulang dari Rumah Sakit. Hasil ukur status gizi dikelompokan menjadi kurang tingkat berat $<17,00 \mathrm{~kg} / \mathrm{m}^{2}$, kurang tingkat ringan $17,00-18,49 \mathrm{~kg} / \mathrm{m}^{2}$, normal $18,50-25,00 \mathrm{~kg} / \mathrm{m}^{2}$, kelebihan berat badan tingkat ringan $25,10-27,00 \mathrm{~kg} / \mathrm{m}^{2}$ dan kelebihan berat badan tingkat berat $\geq 27,00 \mathrm{~kg} / \mathrm{m}^{2}$. Analisis hasil penelitian disajikan secara deskriptif dalam persentase. 
Journal of Holistic and Health Sciences Vol.5, No.1, Januari-Juni 2021 | 4

\section{HASIL PENELITIAN}

Karakteristik subjek penelitian terlihat pada Tabel 1. berikut,

Tabel 1. Karakteristik Subjek

\begin{tabular}{|c|c|c|}
\hline \multirow[t]{2}{*}{ Karakteristik } & \multicolumn{2}{|c|}{ Jumlah } \\
\hline & $\mathrm{n}$ & Persentase (\%) \\
\hline \multicolumn{3}{|l|}{ Jenis kelamin } \\
\hline Laki-laki & 5 & $55,5 \%$ \\
\hline Perempuan & 4 & $44,5 \%$ \\
\hline Total & 9 & $100 \%$ \\
\hline \multicolumn{3}{|l|}{ Usia (Tahun) } \\
\hline $30-45$ & 2 & $22,3 \%$ \\
\hline $46-60$ & 5 & $55,5 \%$ \\
\hline$>60$ & 2 & $22,2 \%$ \\
\hline Total & 9 & $100 \%$ \\
\hline \multicolumn{3}{|l|}{ Diagnosa Medis } \\
\hline Diabetes Mellitus & 5 & $55,5 \%$ \\
\hline Vertigo & 2 & $22,2 \%$ \\
\hline Hipertensi & 1 & $11,1 \%$ \\
\hline Low back Pain (LBP) & 1 & $11,1 \%$ \\
\hline Total & 9 & $100 \%$ \\
\hline \multicolumn{3}{|l|}{ Lama Hari rawat Inap } \\
\hline 7 hari & 3 & $33,4 \%$ \\
\hline 8-10 hari & 4 & $44,5 \%$ \\
\hline$\geq 11$ hari & 2 & $22,3 \%$ \\
\hline Total & 9 & $100 \%$ \\
\hline \multicolumn{3}{|l|}{ Asupan Energi } \\
\hline Sangat kurang & 0 & $0 \%$ \\
\hline Kurang & 2 & $22,3 \%$ \\
\hline Baik & 4 & $44,5 \%$ \\
\hline Lebih & 3 & $33,4 \%$ \\
\hline Total & 9 & $100 \%$ \\
\hline \multicolumn{3}{|l|}{ Asupan Protein } \\
\hline Sangat kurang & 2 & $22,3 \%$ \\
\hline Kurang & 7 & $77,8 \%$ \\
\hline Baik & 0 & $0 \%$ \\
\hline Lebih & 0 & $0 \%$ \\
\hline Total & 9 & $100 \%$ \\
\hline \multicolumn{3}{|l|}{ Status Gizi Awal masuk RS } \\
\hline Kurang tingkat berat & 0 & $0 \%$ \\
\hline Kurang tingkat ringan & 2 & $22,3 \%$ \\
\hline Normal & 4 & $44,5 \%$ \\
\hline Kelebihan berat badan tingkat ringan & 0 & $0 \%$ \\
\hline Kelebihan berat badan tingkat berat & 3 & $33,4 \%$ \\
\hline Total & 9 & $100 \%$ \\
\hline \multicolumn{3}{|l|}{ Status Gizi keluar RS } \\
\hline Kurang tingkat berat & 0 & $0 \%$ \\
\hline Kurang tingkat ringan & 1 & $11,2 \%$ \\
\hline Normal & 5 & $55,6 \%$ \\
\hline Kelebihan berat badan tingkat ringan & 0 & $0 \%$ \\
\hline Kelebihan berat badan tingkat berat & 3 & $33,4 \%$ \\
\hline Total & 9 & $100 \%$ \\
\hline
\end{tabular}


Berdasarkan Tabel 1. hasil penelitian ini menunjukkan bahwa sebagian besar subjek berjenis kelamin laki-laki yaitu sebanyak 5 orang (55,5\%). Usia subjek sebagian besar berusia 4660 tahun (55,5\%) dengan diagnosa medis diabetes mellitus (55,5\%). Lama hari rawat inap terpendek dalam penelitian ini tujuh hari oleh 3 subjek (33,3\%), dan terpanjang $\geq 11$ hari sebanyak 2 orang (22,2\%). Rata-rata asupan energi subjek kategori baik $(44,5 \%)$ dan lebih $(33,3 \%)$, sedangkan rata-rata asupan protein subjek sebagian besar dalam kategori kurang $(77,8 \%)$. Tidak ada perubahan status gizi subjek pada saat masuk dan keluar rumah sakit, hanya ada satu subjek yang meningkat status gizinya dari kurang menjadi satus gizi normal saat keluar rumah sakit.

Tabel 2. Asupan Energi dan Protein Subjek

\begin{tabular}{lccc}
\hline \multicolumn{1}{c}{ Variabel } & n & Median (Min-maks) & Rerata (SD) \\
\hline Asupan Energi (kcal) & 9 & $1116,2(1055,50-1488,80)$ & $1151,20(133,19)$ \\
\hline Asupan Protein (g) & 9 & $26,77(25,27-35,53)$ & $27,70(3,15)$ \\
\hline
\end{tabular}

Berdasarkan Tabel 2. Rata-rata asupan energi subjek sebesar 1151,20 kcal, asupan energi minimum dan maksimum sebesar 1055,50 kcal dan

\section{PEMBAHASAN}

Lama hari rawat inap pasien dengan positif diet di RSUHP terpendek adalah 7 hari $(33,3 \%)$ dan terpanjang $\geq 11$ hari $(22,3 \%)$ hasil ini senada dengan data profil kesehatan Kabupaten Purwakarta tahun 2019 bahwa pasien rawat inap di RSUHP memiliki rata-rata hari rawat inap terpanjang yaitu 9-14 hari. Hasil ini berbeda dengan penelitian yang dilakukan oleh Tarigan (2019) pada pasien yang tidak berdiet khusus di RSUD dr. Moewardi lama hari rawat inap pasien kategori pendek ( $<4$ hari) 5,2\% dan kategori panjang (>7) 43,6\%. ${ }^{3}$ Lamanya hari rawat inap pasien di RSUHP berkaitan dengan program terapi yang diberikan, dimana setiap pasien akan diberikan program terapi minimal 7-14 hari, terapi ini meliputi terapi diet sebagai terapi utama, terapi fisik, terapi herbal dan suplement makanan, serta terapi komplementer lainnya yang mendukung kesembuhan pasien.

Status gizi subjek pada penelitian ini diukur saat masuk dan keluar rumah sakit. Tidak ada perbedaan signifikan status gizi di antara keduanya. Asupan protein yang kurang, namun porsi karbohidrat tinggi dapat menghasilkan total asupan energi sesuai kebutuhan.
1488,80 kcal. Rata-rata asupan protein subjek sebesar 27,7 gram, asupan protein minimum dan maksimum sebesar 25,27 gram dan 35,53 gram.

Leandro-Merhi (2015) dalam penelitiannya melaporkan bahwa penurunan berat badan pada pasien rawat inap tidak berhubungan dengan usia dan jenis diet yang diberikan, namun berhubungan dengan jenis penyakit neoplasma dan jenis kelamin laki-laki mengalami penurunan berat badan yang signifikan selama perawatan di rumah sakit. ${ }^{9}$

Asupan makan merupakan faktor utama untuk memenuhi kebutuhan gizi sebagai sumber tenaga, mempertahankan ketahanan tubuh dalam menghadapi serangan penyakit dan untuk pertumbuhan. ${ }^{10}$ Asupan makanan yang rendah selama rawat inap diketahui sebagai faktor risiko kematian selama dirawat di rumah sakit. Tingkat asupan makan saat dirawat di rumah sakit dapat dipengaruhi beberapa faktor baik dari segi kondisi pasien seperti perasaan "tidak lapar", "tidak menyukai rasa/aroma makanan", tidak berselera makan, perasaan mual dan lemah selama dirawat, serta jenis penyakit/tindakan medis yang sedang dijalani,11 maupun dari segi kondisi lingkungan seperti makan di tempat tidur, makan sendirian dan pengaruh negatif dari pasien lain 
dalam satu kamar rawat yang dapat memengaruhi keinginan untuk makan. ${ }^{12}$

Asupan energi menjadi salah satu indikator penting untuk kesembuhan pasien karena pasien rawat inap dengan asupan energi yang kurang memiliki resiko lebih tinggi untuk mengalami malagizi dan akan pulang dalam keadaan tidak sembuh lebih besar 3,5 kali dibanding pulang dalam keadaan sembuh $^{13}$. Tujuan terapi makanan positive diet di RSUHP adalah memberikan makanan sesuai dengan kondisi pasien untuk detoksifikasi dan mencegah serta mengurangi kerusakan jaringan tubuh. Dalam penelitian ini sebagian besar asupan energi subjek baik sesuai dengan kebutuhan, meskipun begitu asupan protein subjek dilaporkan rendah dan sangat rendah. Asupan protein sangat erat kaitannya dengan proses pemulihan pasien. Asupan protein efektif untuk manajemen berat badan, karena meningkatkan rasa kenyang, pengeluaran energi, dan mengubah komposisi tubuh demi massa tubuh bebas lemak (lean body mass). ${ }^{14}$ Asupan protein yang rendah dipengaruhi pula oleh porsi dan jenis protein yang diberikan dalam menjalani positive diet. Sumber protein utama yang diberikan adalah protein nabati seperti tahu, tempe dan kacang-kacangan. Sumber protein hewani seperti ikan kembung, ikan gindara, telur dan daging ayam kampung diberikan dalam penangan kasus tertentu, sedangkan protein yang berasal dari daging merah tidak diberikan. Pada penelitian kohort prospective dilaporkan bahwa konsumsi protein nabati yang lebih tinggi dibandingkan protein hewani memiliki hubungan dengan risiko kematian yang lebih rendah. Modifikasi pola makan dalam pemilihan sumber protein dapat mempengaruhi kesehatan dan umur

\section{KETERBATASAN PENELITIAN}

Penelitian ini memberi gambaran lama rawat dan asupan energi dan panjang. ${ }^{15} \quad$ Studi epidemiologi menunjukkan bahwa asupan protein hewani yang tinggi, terutama daging merah, yang mengandung metionin dan BCAA tinggi, mungkin terkait dengan peningkatan penyakit terkait usia (penyakit degeneratif). Oleh karena itu, diet rendah protein hewani, khususnya diet rendah daging merah, dapat memberikan manfaat kesehatan. ${ }^{16,17}$

Kecukupan asupan energi dipengaruhi pula oleh lemak. Sumber lemak yang diberikan dalam positive diet hanya minyak zaitun dan minyak jagung. Hasil penelitian meta analisis yang dilakukan oleh Tsartsou (2019) efek penting dari polifenol minyak zaitun adalah peningkatan kolesterol HDL, dan perbaikan status antioksidan dan inflamasi.18 Guasch-Ferre (2020) menyatakan dalam studinya pada populasi Mediterania bahwa substitusi margarin, mentega, mayonnes, dan lemak susu dengan minyak zaitun dapat menurunkan risiko PJK dan CVD. ${ }^{19}$ Studi yang dilakukan oleh Maki et al (2018) di Chicago menemukan konsumsi makanan yang menyediakan minyak jagung 54 gram/hari menghasilkan profil lipid plasma yang lebih baik daripada minyak kelapa pada orang dewasa dengan kolesterol tinggi. Porsi pemberian makanan positive diet terbagi menjadi porsi kecil (50\% kebutuhan kalori), porsi sedang $(75-100 \%$ kebutuhan kalori), dan porsi besar $(>100 \%$ kebutuhan kalori). Parameter penyembuhan lingkungan mulai dari kualitas udara dan pemandangan alam serta layanan rumah sakit yang humanis mampu menciptakan psikologis pasien semakin baik sehingga dapat meningkatkan selera makan pasien. Semakin lama hari rawat inap pasien kecenderungan memiliki asupan energi baik dan lebih.

protein khususnya di RSUHP yang ratarata memiliki rentang lama rawat pasien 
lebih lama dibandingkan rumah sakit pada umumnya, namun begitu keterbatasan dalam penelitian ini terkait dengan kondisi pandemi COVID-19 sehingga jumlah subjek belum dapat mewakili RSUHP. Selain itu, desain

\section{SIMPULAN}

Lama hari rawat inap yang panjang pada pasien yang mendapatkan positive diet memiliki asupan energi baik, asupan protein kurang dan status gizi normal. penelitian cross-sectional dalam penelitian ini tidak memungkinkan untuk membuat kesimpulan kausal, walau begitu dalam analisis kami menyertakan beberapa faktor yang berpengaruh dengan hati-hati.

Perlu dilakukan penelitian lebih lanjut dengan kasus yang berbeda agar bisa menggambarkan proses pemberian positive diet secara keseluruhan.

\section{DAFTAR PUSTAKA}

1. Awad A, Bader-El-Den M, McNicholas J. Patient length of stay and mortality prediction: A survey. Heal Serv Manag Res. 2017;30(2). doi:10.1177/0951484817696212

2. Tarigan PB. Hubungan Lama Hari Rawat Inap Dengan Perubahan Berat Badan, Asupan Energi dan Protein pada Pasien yang Tidak Berdiet Khusus di RSUD. Dr. Moewardi. J Chem Inf Model. 2013;53(9).

3. Correia MITD, Perman MI, Waitzberg DL. Hospital malnutrition in Latin America: A systematic review. Clin Nutr. 2017;36(4). doi:10.1016/j.clnu.2016.06.025

4. Fatonah S, Rihiantoro T, Irawan H, Ari S, Nurdiantini, I., Prastiwi, S., \& Nurmaningsari T. Nursing News Volume 1, Nomor 2, 2016. J Nurs News. 2012;XI(1). doi:10.1021/BC049898Y

5. Pirlich M, Schütz T, Norman K, et al. The German hospital malnutrition study. Clin Nutr. 2006;25(4). doi:10.1016/j.clnu.2006.03.005

6. Graham BL, Steenbruggen I, Barjaktarevic IZ, et al. Standardization of spirometry 2019 update. Am J Respir Crit Care Med. 2019;200(8).

7. Yani A, Nursoleha N, Zein LF. TATA LAKSANA GIZI HOLISTIK PADA PASIEN PENYAKIT GINJAL KRONIK DENGAN HIPERTENSI RAWAT INAP DI RSU HOLISTIC PURWAKARTA. J Holist Heal Sci. 2021;4(2). doi:10.51873/jhhs.v4i2.83

8. Dinas Kesehatan Kabupaten Purwakarta. Profil Kesehatan Kabupaten Purwakarta.; 2019.

9. Leandro-Merhi VA parecid., Srebernich SM arian., Gonçalves GM ar. S, de Aquino JLB rag. In-hospital weight loss, prescribed diet and food acceptance. Arq Bras Cir Dig. 2015;28(1). doi:10.1590/S0102-67202015000100003

10. Crespo CS, Cachero AP, Jiménez LP, Barrios V, Ferreiro EA. Peptides and food intake. Front Endocrinol (Lausanne). 2014;5(APR). doi:10.3389/fendo.2014.00058

11. Koyuncu A, Yava A, Aslan FE. Determination of food intake and the factors affecting food intake in perioperative period in patients who undergo open heart surgery.

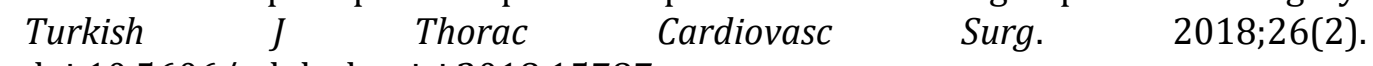
doi:10.5606/tgkdc.dergisi.2018.15787

12. Kontogianni MD, Poulia KA, Bersimis F, et al. Exploring factors influencing dietary intake during hospitalization: Results from analyzing nutritionDay's database (2006-2013). Clin Nutr ESPEN. 2020;38. doi:10.1016/j.clnesp.2020.04.001

13. Rahmayati E, Asbana Z Al, Aprina. Hubungan Antara Faktor Individu, Sosio Demografi, dan Administrasi dengan Lama Hari Rawat Pasien Rawat Inap Rumah Sakit Pantai Indah Kapuk Tahun 2011. J Keperawatan. 2017;XIII(2).

14. Drummen M, Tischmann L, Gatta-Cherifi B, Adam T, Westerterp-Plantenga M. Dietary protein and energy balance in relation to obesity and co-morbidities. Front 
Journal of Holistic and Health Sciences

Vol.5, No.1, Januari-Juni 2021 | 8

Endocrinol (Lausanne). 2018;9(AUG). doi:10.3389/fendo.2018.00443

15. Huang J, Liao LM, Weinstein SJ, Sinha R, Graubard BI, Albanes D. Association between Plant and Animal Protein Intake and Overall and Cause-Specific Mortality. JAMA Intern Med. 2020;180(9). doi:10.1001/jamainternmed.2020.2790

16. Levine ME, Suarez JA, Brandhorst $S$, et al. Low protein intake is associated with a major reduction in IGF-1, cancer, and overall mortality in the 65 and younger but not older population. Cell Metab. 2014;19(3). doi:10.1016/j.cmet.2014.02.006

17. Song M, Fung TT, Hu FB, et al. Association of animal and plant protein intake with all-cause and cause-specific mortality. JAMA Intern Med. 2016;176(10). doi:10.1001/jamainternmed.2016.4182

18. Tsartsou E, Proutsos N, Castanas E, Kampa M. Network Meta-Analysis of Metabolic Effects of Olive-Oil in Humans Shows the Importance of Olive Oil Consumption With Moderate Polyphenol Levels as Part of the Mediterranean Diet. Front Nutr. 2019;6. doi:10.3389/fnut.2019.00006

19. Guasch-Ferré M, Liu G, Li Y, et al. Olive Oil Consumption and Cardiovascular Risk in U.S. Adults. J Am Coll Cardiol. 2020;75(15). doi:10.1016/j.jacc.2020.02.036 